\author{
A.M. Malikov \\ Palacký University Olomouc, \\ Křižkovského 511/8, Olomouc, 77147, Czech Republic \\ E-mail: azimmal2018@gmail.com
}

\title{
Celebration of Nowruz in Bukhara and Samarkand in Ritual Practice and Social Discourses (the Second Half of the 19th to Early 20th Centuries)
}

\begin{abstract}
Celebration of Nowruz across a vast territory from the Ottoman Empire to Xinjiang had both common features and differences. This study focuses on distinctions between the festive traditions of two major cities of the Zerafshan Valley (Bukhara and Samarkand) in the late 1800s and early 1900s, when, after Russia 's annexation of the region, the Nowruz ritual practices were transformed and subjected to critical discourses among theologians and enlighteners. On the basis of unpublished archival sources, memoirs, and studies of Imperial Russian history, I analyze two types of Nowruz: official and folk. In the Emirate of Bukhara, a broad official celebration of Nowruz was started by Emir Muzaffar, who sought to strengthen the image of the Manghit dynasty during the crisis of political legitimacy. This gave rise to disputes among Islamic intellectuals about the need for a large-scale and prolonged celebration of Nowruz, which they felt went beyond the borders of Islamic tradition. In Samarkand, closer contacts between the settled Tajiks and Uzbeks, on the one hand, and the semi-nomadic Turkic-speaking population, on the other, enhanced the synthesis of agricultural and pastoral elements in the ritual practice of Nowruz. The festival was legitimized by prayers at mosques, and visits to the mazars of Muslim saints and to sacred streams. In Samarkand, following its annexation by the Russian Empire, there was no official celebration of Nowruz, and the scale of popular celebration decreased.
\end{abstract}

Keywords: Islam, Zerafshan Valley, ritual practice, discourses, legitimation.

\section{Introduction}

Celebration of Nowruz is one of the ancient traditions of the peoples of Central Asia and the Middle East. In ancient times, this festival was linked with the ideas of nature's death and return to life, mixed up with other cultural components depending on the region and period. The complicated connotation of this holiday was reflected in combinations of various beliefs and ritual practices.

The purpose of this study was to collect information concerning the celebration of Nowruz in Bukhara and Samarkand, two major cities in the Zerafshan Valley (situated in the middle portion of Central Asia) from the second part of the 19th century to the early 20th. This period shows transformation, upon annexation of this region by the Russian Empire, in the Nowruz celebration; the relevant ritual ceremonies; and the existing discourses among theologians and enlighteners. The Nowruz phenomenon is of considerable interest, because despite the dominance of Islam, it preserved certain nonIslamic features throughout many centuries. The political establishment celebrated Nowruz officially for the purpose of propagating the positive image of the ruling dynasty.

Formerly, two types of Nowruz celebration existed: the first was celebrated in mid-summer; the second

Archaeology, Ethnology \& Anthropology of Eurasia 48/2 (2020) 122-129 E-mail: Eurasia@archaeology.nsc.ru (C) 2020 Siberian Branch of the Russian Academy of Sciences

(C) 2020 Institute of Archaeology and Ethnography of the Siberian Branch of the Russian Academy of Sciences (C) 2020 A.M. Malikov 
was confined to the day of the vernal equinox. The official Nowruz celebration did not always coincide with the folk festival. Legends bound the advent of this festival with the names of the mythical Iranian kings-Kayumars and Jamshid (Braginsky, 1977: 116). The formal Nowruz celebrations were practiced in the Sasanian Empire and in Samarkand, the capital of Sogd, in the 7th to 8th centuries (Grenet, 2006).

Official celebrations of Nowruz in Bukhara were described in the works by the renowned enlightener of the 19th century Ahmad Donish (1827-1897) (Traktat..., 1967: 90-92) and an outstanding Tajik writer S. Ayni (1878-1954) (1960: 831-832). J. Locke, a British citizen, also published his impressions of this festival (1906).

The first analytical works on Nowruz celebration in the Zerafshan Valley were published in the late 19 th to early 20th centuries. Researchers of the period of the Russian Empire mostly defined Nowruz as a nonIslamic festival with certain Aryan features. The authors, who described the customs of Samarkand citizens, were state officials and scholars with a good knowledge of this region (G. Arendarenko, A. Grebenkin, A. Khoroshkhin, N. Veselovsky, and V. Vyatkin).

Soviet orientalists and ethnologists also wrote about Nowruz and spring festivals (Snesarev, 1969: 205-215; Braginsky, 1977; Ustaev, 1985; Sukhareva, 1986; Lobacheva, 1986; and others). They made their important contribution to the studies of the festive rituals by analyzing various social, religious, and domestic festivals and their role in the cultural life of the people. Valuable information on the organization of the official celebration of Nowruz during the reign of Emir Muzaffar and Emir Abdulahad can be found in the works of the Ethnographic Expedition to Bukhara headed by M.S. Andreev in 1940; members of this expedition included researchers of the University of Central Asia and museums-M.S. Yusupov, N.V. Rusinova, O.D. Chekhovich, and L.I. Rempel (Andreev, Chekhovich, 1972: 9-10). Some records were published, and others are deposited as the personal archive of Chekhovich in the Central State Archive of the Republic of Uzbekistan and other archives of Uzbekistan and Tajikistan. It should be noted that the data were recorded from many interviewees; their descriptions of the festival details vary. The present study is mostly based on the materials collected by Chekhovich.

In the Soviet period, Nowruz was studied as a set of folk rituals of non-Islamic origin, while the impact of Islam on the ritual practice of this festival was disregarded. Some researchers considered this festival non-religious, secular (Braginsky, 1977: 118); others acknowledged its close relations with Islam (Rempel,
1981: 63). In the post-Soviet period, Nowruz was regarded as not only the ancient Iranian festival of the vernal equinox, but also as a specific feature of Central Asian Islam (Rakhimov, 2012: 151). The most wellknown papers on the Nowruz history were republished, together with new works on this topic, in the collection of papers "The Magic of Nowruz" (Magiya Navruza, 2007).

In our view, Nowruz is a combination of ideas of the Central Asian Muslim population with various cultural backgrounds. There have still been no special studies on official celebration of Nowruz in various Central Asian khanates, on its distinctions from folk ritual, or on the existing discussions on this topic.

In the Emirate of Bukhara, in the 19th century, the calendar festival of Nowruz included a complex of events, reflecting distinct beliefs of both the sedentary agricultural and the nomadic pastoralist populations. It is noteworthy that during particular periods, this festival served as an instrument for popularizing the positive image of the ruling dynasty.

We can seek understanding of the non-Islamic Nowruz festival through analysis of rituals and their transformation in the Islamic tradition and in the context of the political and social situation in the Emirate of Bukhara. There are several definitions of a ritual. According to V. Turner, "it is a stereotyped succession of actions including gestures, words, and objects, which are executed in the specially prepared place and are aimed at affecting supernatural forces..." (1983: 32). He identifies seasonal rituals dedicated to the moments of change in the natural cycle or to the beginning of sowing and harvesting; divination; "ceremonies performed by political authorities to ensure the health and fertility of the people and the cereals in their country"; rituals accompanying offerings to ancestral spirits, etc. (Ibid.). The rituals served as instruments of integration of various social groups. The integrating effect of festivals depended on the interrelations between groups, which might have varied during the celebrations. When the rituals are repeated throughout many years, they become integral parts of the tradition (Etzioni, 2004: 7, 16). The tradition is conceptualized as variations of the long-term discourses, but not as a set of invariable doctrines or repetition of former beliefs and practices (Haj, 2009: 4, 6).

\section{Fests and generally accepted rituals related to Nowruz}

In Central Asia, Nowruz was traditionally a festival of spring, new year, and the start of agricultural work. 
Little information is available concerning the Nowruz celebration in ancient times. Notably, prior to the penetration of Islam in this region, the ideological content of Nowruz was connected with the local varieties of Zoroastrianism. Under the conditions of polytheism, various cults, worship of fire, and praying in temples became wide-spread. Sacrifices were conducted, sporting games took place, and fairs were held in towns (An-Narshakhi, 2011: 222, 226). With the introduction of Islam, the situation changed. Some renowned Muslim theologians argued against spectacular celebrations of Nowruz. According to Abu Hamid Muhammad alGhazali (1058-1111), “...the New Year and sada* should disappear, and nobody should pronounce their names..." (2018: 296). However, celebration of Nowruz survived and was even adopted by the semi-nomadic part of the Turkic population of Central Asia. The centuries-long discussion among the theologians of Central Asia about the possibility of Nowruz celebration by the Muslims ended with the legalization of this festival; it was celebrated along with other Islamic holidays - Eid al-Fitr (Id al-fitr - festival of the end of fasting) and Eid al-Adha (Id al-adha - festival of the sacrifice) (Veselovsky, 1888: 141). With the adoption of Islam, Nowruz acquired certain Muslim features (Lobacheva, 1995: 25).

In the medieval period, various traditions of Nowruz celebration existed. However, in the ritual practice of the population of Central Asia and Iran, many similar features in celebration of this spring holiday can be observed: cooking special ritual meals-gudzha and sumalyak, which were meant to ensure a rich harvest in the current year and the well-being of women participants of this ritual (Snesarev, 1969: 211, 215); sprinkling each other with water (Braginsky, 1977: 118); coloring chicken eggs; and worship of ancestors, which rituals were also noted among the Uyghurs of East Turkestan (Dorzhieva, 2016: 62-79).

Nowruz was the highest point in the cycle of monthlong spring holidays (Sukhareva, 1986: 34). One of these was the red flower festival (tulip or poppy, sayli guli surkh, kizil gul sayli), which was celebrated in many regions of the Central Asian interfluve area (Ibid.: 34-38), and by the Uyghurs of East Turkestan. Sayls (folk festivities) were carried out in April to early May, when poppies and tulips blossomed. Before and during Nowruz, festivals of other flowers, for instance snowdrops (boichechak), were celebrated.

In general, the ritual practice of Nowruz celebration is common over the vast territory of central and eastern parts of the Islamic realm. On the other hand, celebration of this

\footnotetext{
*The ancient Zoroastrian festival of fire.
}

holiday had certain distinctive features in oases of Central Asia, specifically in the towns of the Zerafshan Valley.

\section{Official celebration of Nowruz in Bukhara, and the discourses of intellectuals}

Researchers noted that monarchs and clergy tried to introduce certain religious and monarchic features into Nowruz celebration (Braginsky, 1977: 120). In Bukhara, during the reign of Emir Nasrulla (1827-1860), the ruler had the right to prolong Nowruz celebrations. According to P.I. Demezon, the festival usually lasted for six days. Once, the Emir extended the folk festivities to 15 days and did his best to participate in the gaieties more than usual (Zapiski..., 1983: 70).

In the second half of the 19th to early 20th centuries, Nowruz in Bukhara was celebrated in both official and folk ways. S. Ayni, a philosopher and writer from Bukhara, wrote that folk festivities started long before this spring holiday, and (in contrast to those arranged by the Emirate authority) were carried out every Friday from February 22 till March 22 at the Fayzabad sanctuary, to the northeast of Bukhara. The festivities were accompanied by various sports competitions (races, wrestling) between residents of various villages (Ayni, 1960: 235-246). Ayni noted that Eid al-Adha and Ramadan were celebrated for 1 day each, while Nowruz lasted for several weeks. Though this festival was linked with wheat and barley sprouting, and with the start of other crop-sowing, the clergy gave much significance to its religious connotation (Ibid.: 826-827).

Nowruz gained its official form during the reign of Emir Muzaffar (1860-1885), after defeat in the war with the Russian Empire in 1868. According to the informants of Ayni, Muzaffar, having lost his public image, arranged popular festivities during the celebration, "in order to avert people's eyes from his improper deeds". Wrestlers and spectators were invited from the Bukhara regions of Qarshi, Shakhrisabz, Khatyrchi, Kermine, and Nur-Ata. The festivals were held in the suburban Emir garden of Shirbadan (Shirbudun) and lasted up to two months, sometimes up to 70 days (Ibid.). The religious holidays of Ramadan and Eid al-Adha were arranged by the Bukhara clergy, but the official celebration of Nowruz was carried out by the Emirate authority, which used this opportunity in their political, ideological, social, and economic interests. Ayni explained how the Emir managed to assign so much importance and popularity to this non-Islamic festival, given the existence of an influential and conservative clerical class of ulama in Bukhara, which class included theologians, lawyers, 
teachers from madrasas, and experts in Sharia-qazis and muftis (Sukhareva, 1966: 297): upon signing the peace treaty with the Russian Empire, Muzaffar managed to override the clergy and made them the "instruments of his power" (Ayni, 1975: 294).

Rempel noted that during the arrangement of Nowruz "religious and commercial events", military officers (udaychi and sarkarda) looked after the chadyrs (stalls) belonging to officers, bais, merchants, and artisans. The festivities were accompanied by performances by strolling players, wrestlers, etc. Sayl lasted up to 40 days (Rempel, 1981: 63-64). The ethnic background of the invited merchants and artisans varied (Tajiks, Uzbeks, Iranians, Afghans, and others).

During the reign of Emir Abdulahad (1885-1910), in Shirbadan, two enclosed areas for the festival were made. One of these was named "forty tanob" (10 ha). The area included Juma mosque, walking areas, various constructions for performances; the rest of the place was occupied by merchants. The other enclosed area was named "seventy tanob" (18 ha); it was the place for the festive tents of military commanders and principal merchants (Ayni, 1960: 827-829). The festive ceremonies included rituals performed by ishans, the leaders of the Sufi communities. The master of the festivities was the supreme judge or rais of Bukhara (Ibid.), which fact supports the idea of the state and religious legitimization of Nowruz.

According to Chekhovich, "every year, on the 18th of March, festivities were arranged in the Shirbadan garden of the Emir of Bukhara. The plan for the disposition of guests was made. The sheds were constructed according to the social background of the guests. The best places were assigned to Uzbek military commanders, while merchants got a smaller number of seats. The highest rank was given to the military commander tupchi bashi or amir lashkar; he was provided with the largest shed. Smaller tents were given to Sarbaz military commanders, commanders of the troops el-nuker, and traders" (Central State Archive of the Republic of Uzbekistan (CSA RUz). R-2678, Inv. 1, Item 448, fol. 14). The stalls were decorated with adras and shokhi fabrics, various carpets, blankets, and cushions. 300 lanterns were installed for night-time illumination (Ibid). Up to 70 small traders attended the festival; each trade was represented by 4 to 10 persons. During the reign of Emir Muzaffar, sayls, including Nowruz, lasted for 70-80 days, when the state officers were awarded with gifts from the Emir. The sayl was attended by guests and merchants from various regions of the Emirate of Bukhara, Afghanistan, Fergana, Samarkand, Khwarazm, Kashgar, and Mashhad. Stalls were allowed to be established in the garden of Shirbadan only by the selected merchants from Samarkand, Kabul, Urgench, Mashhad, and Peshawar (Ibid.). In order to emphasize his own eminence, the Emir arranged the festivities in his garden, where one of the Emir's palaces was later constructed. There were no sanctuaries in the garden; hence, the only ritual was the joint prayer in the mosque, which was followed by sporting events, amusements, and awarding gifts to the winners and associates.

After the official events, there was a three-day sayli mazor - visiting by women of the Bukhara mazars of the Islamic saints Ismail Samani and Chashma-Ayub; and visiting by men of the cemetery of Khoja Ismat (Rempel, 1981: 63-64). Notably, further spring holidays of the Bukhara people took place at the sanctuary of Baha-ud-Din Naqshband Bukhari (1318-1389), the religious leader of the Naqshbandi order, and the other most popular mazars of Bukhara.

When the Russian Empire set a protectorate over the Emirate of Bukhara, on the 21st of March, the GovernorGeneral of Turkestan sent a delegation to Bukhara to congratulate Emir with Nowruz (Abdirashidov, 2011: 138, 146). Apparently, the members of this delegation attended the official celebration ceremonies in the Shirbadan garden. Ayni noted that in the early 20th century, Russian circus artists performed at the festival (1960: 829-833). These artists were invited by Emir Abdulahad, who on the one hand, possibly wanted to present diverse performances to the guests and on the other hand, copied the Turkestan authorities in inviting circus artists from the European part of Russia. Accordingly, non-Islamic people were allowed to participate in the festivities of the Muslim population in Bukhara, and this innovation was well received by the local people.

The Nowruz celebration in Bukhara was described by the British subject J. Locke, who attended the official events in the Emir's palace in March 1904. As an honored guest, he had an opportunity to watch the performances from the Emir's box. He even took several photographs of musicians, wrestlers, and spectators during the holiday. Locke watched 5000 guests perform joint namaz before the beginning of the festival (1906).

Data on the dynamics of the Nowruz celebration in the second half of the 19th century to early 20th century are inadequate. There is only information on the changes in duration and location of the celebrations. According to Ayni, during the reign of Abdulahad, the duration of Nowruz celebration was reduced to a month and a half. The festivities started in the Shirbadan garden, continued in the suburban palace of Sitorai MokhiKhosa and in the town of Kermine, where the Emir stayed for the greater part of his time (Ayni, 1960: 
826-828). During the reign of Emir Alim-Khan (1910 1920), the Nowruz celebration became even shorter, and took place in the Sitorai Mokhi-Khosa garden in Bukhara (CSA RUz. R-2678, Inv. 1, Item 448, fol. 20).

Some intellectuals in Burkaha, including the philosopher Ahmad Donish, were critical of broad and lavish celebrations of Nowruz. Donish wrote that "the celebration of the new year was among the new customs, which became widely spread during the reign of this Emir (Muzaffar - A.M.)" (Traktat..., 1967: 90-91). Donish acknowledged islamization of this festival. He wrote that it is "surprising that sheikhs of the town, together with murids, were also invited to attend the festival. Getting together in a circle, they recited Masnavi Mawlawi. At some other place, dhikr was performed, and still elsewhere the Quran was recited..." (Ibid.). However, Donish criticized the organization of this festival: he argued that it was “... a bazaar of debauchery and gambling..." (Ibid.: 91-92). He noted that "during the reign of Emir Muzaffar, general decline and disorder became apparent in Islam. Sharia was derogated by the regime..." (Ibid.: 94-95). Donish's viewpoints concerning the necessity of limiting the squandering were shared by the Bukhara reformers in the early 20th century (Samoylovich, 1922: 98). Criticism by influential Islamic intellectuals of the lavish celebrations was probably among the reasons to cut down the scale and duration of the official Nowruz celebration in Bukhara during the reigns of Emir Muzaffar's successors.

Following the weighty opinion of S. Ayni, we believe that in Muzaffar's period, there were two types of Nowruz celebration in Bukhara: official and folk. For official ceremonies, the authorities invited guests from other cities and countries; folk celebrations were mainly attended by the residents of Bukhara oasis. The festivities were perceived by the common people as a family holiday and worship of their ancestors, along with the Islamic religious rituals (Rempel, 1981: 63).

Emirs of Bukhara exploited Nowruz official celebrations to achieve certain political, ideological, social, and economic tasks. Centralized organization of the festival, on the one hand, was aimed at consolidation of political and economic elites in Bukhara, which were dissociated because of the defeat of the Emirate in the war with the Russian Empire. On the other hand, the authorities demonstrated to common people an image of power that followed ancient traditions, consecrated by the Muslim clergy. Under conditions of economic crisis, broadening the scale of the Nowruz celebration, with markets being established and local and foreign traders invited, might have produced a positive effect on the economy of Bukhara.

\section{Celebration of Nowruz in Samarkand}

Samarkand, situated in the Middle Zerafshan Valley, was a Muslim city, known for its Islamic shrines and mosques. The city had its own original features and local identity, which has not been well studied by researchers. Since long ago, this polyethnic city was populated by Tajiks, Uzbeks, Iranians, Jews, Turkmens, Tatars, and others. While the surroundings of the capital city of Bukhara were mostly populated by the sedentary agricultural people, Samarkand was surrounded by the settlements of semi-nomadic or settled Turkic pastoralists.

One of the elements of the Samarkand urban culture was the equestrian sport kupkari (ulak, kok-boru), typical of the pastoralist population. The game was normally carried out in March and October, on the occasion of weddings, circumcision of juveniles (Arendarenko, 1877), and during Nowruz celebrations. The game likely became a part of the Samarkand urban culture in the late medieval period, when the semi-nomadic population groups settled in the Samarkand oasis (Malikov, 2018: 120-122). Moreover, during Nowruz celebrations, wrestling competitions were carried out in the region of Khoja Ahror, the best wrestlers being Volga Tatars and Uzbeks (Grebenkin, 1872: 39).

The sacred places in Samarkand, where Nowruz was celebrated, in the 19th century were located around the Registan square, cult complex Shah-i-Zinda, and the ancient ruins of Afrasiyab. In the Namazgah mosque, situated in the southeastern outskirts of Samarkand, joint namaz was performed; and in the adjoining large garden with ponds, the subsequent folk festivities (sayl) took place (Rossiya..., 1913: 677). On the day of Nowruz, the citizens visited the irrigation ditch ObiMashhad, near Shah-i-Zinda. Some researchers believe that the image of Shah-i-Zinda, a saint from Samarkand, was related to Nowruz and to the cult of Siyavash (a hero from the sacred book of Zoroastrianism "Avesta" and the Persian epic poem "Shahnameh") (Rempel, 1972: 45). Thus, there is a fusion of the Islamic idea of sacrifice for the sake of religion and non-Islamic ideas of the cults of various saints, including Siyavash.

According to A. Khoroshikhin, in the first decade following annexation of Samarkand by the Russian Empire, large-scale participation in the celebration of Nowruz was greatly reduced. The main events (sayl with bathing) took place at Obi-Mashhad spring, outside Shah-i-Zinda (Khoroshikhin, 1876: 207). V. Vyatkin interpreted Nowruz as the Muslim New Year, but with a number of rituals and customs in common for all Aryan people, which he opposed to the Islamic traditions (1897). According to him, the general schedule of 
the New Year celebrations surviving in Samarkand till the end of the 19th century included the following events: 1) setting fire and walking with torches at the irrigation ditch Obi-Rakhmat; 2) bathing in the ditch; 3) prophecies; 4) drinking of enchanted water; 5) kazan tuld $y^{*} ; 6$ ) eating of meat, predominantly poultry; 7) mutual gifts of colored boiled eggs; 8) climbing the hills; 9) paying visits; 10) festivities outside the city, races with goat, wrestling, and other events (Ibid.).

Special torches atash baidak (mashal) were prepared for Nowruz in Samarkand. These were lit, and Samarkand citizens gathered together in groups of particular districts and suburban villages, and proceeded to the channel Obi-Rakhmat, where men bathed in order to wash out their sins (Ibid.). The name of the channel had sacral significance. The parallels can be found in southern Uzbekistan among the Derbent people, who believed that before Nowruz there were four days when the water became blessed- "obi rakhmat" (March 14-17). In rainy days, people collected rain water and bathed in it (Ustaev, 1985: 99-100). Widespread occurrence of this custom is supported by the recorded legend about the holy water "obi rakhmat" in the Shafirkan District of the Bukhara Region (Field materials of the author. Shafirkan Tuman, Bukhara Region, Republic of Uzbekistan, 2001).

Before Nowruz, in Samarkand, prophecies salnama (Pers. 'yearly charter'), made by astrologers munajim for a fee, were distributed among nobilities, wealthy people, and acquaintances (Vyatkin, 1897). There were "Sal-name" charters in Turkic. One such charter has survived to the present; it was copied in Bukhara in the early 19th century. The charter narrated the years of the twelve-year "animal" cycle and the relevant signs, forecasting the features of the coming year, depending on what day of week Nowruz happened to be (Shcherbak, 1974: 171-179). Immediately before the holiday, sheets of paper containing the written ayahs from the Quran with good wishes, and colored boiled eggs were on sale. Every family cooked food in full cauldrons (kazan tuldy) to ensure a good harvest in the coming year. Festivities were usually carried out on elevated places, with the aim of getting a high position and growing rich (Vyatkin, 1897). The festival sayli guli surh, following Nowruz, took place at Chupan-aty mazar (Sukhareva, 1986: 33).

In the early 20th century, Samarkand reformists took Nowruz celebrations ambiguously. For example, an article in the Oyina Journal recommended shortening the 40-days-long festival of Nowruz to three days

*Literary 'cauldron is full' (Turkic) - the custom of cooking food in the full cauldrons.
(Abdirashidov, 2011: 217). However, the reformists admitted that this holiday was a part of the religion practiced by the Muslim population of this region (Siddikiy Azhziy, 2005: 142-b).

Upon annexation of the region by the Russian Empire, two major parts were formed in Samarkand: Muslim and European. Residents of each part had their peculiarities and their own perceptions of the city's identity. Russian authorities tried to regulate celebration of Nowruz and other Muslim holidays in Samarkand according to Russian legislation. On the 29th of March 1908, lieutenant-colonel Martinson, an acting head of the Samarkand uyezd, issued a decree on the fee for the plots for the erection of swings, merry-go-rounds, and show-booths during the local festival sayl*, which was carried out at Afrasiyab (ancient ruins of Samarkand), and during the Easter celebration in the Russian part of the city. The decree was confirmed by the military governor of the region on the 29th of April in the same year (CSA RUz. F. I-18, Inv. 1, D. 8854, fol. 2). This document shows that during the Russian administration, at least by the early 20th century, several sacred places were formed in the city, depending on the religiousconfessional identity of the citizens. European citizens celebrated their festivals in the European part of the city, while the Muslim population used Afrasiyab, sacred mazars, and mosques for their holidays.

\section{Conclusions}

The old holiday of Nowruz was traditionally celebrated by the Muslim community of Central Asia, despite the predominance of the Islamic ideology. In the Emirate of Bukhara, the broad official celebration of this holiday began during the reign of Emir Muzaffar, who sought to support the image of the Uzbek dynasty of Manghit during the crisis of political legitimacy resulting from defeat in the war with the Russian Empire, and to consolidate the commercial, military, and political elites of the country. In the early 20th century, Emir Abdulahad of Bukhara initiated the participation of the non-Muslim Russian circus artists in the festival.

The celebration of Nowruz combined the non-Islamic beliefs and the Islamic interpretation of the festival, which was legitimized by prayers at mosques and visits to mazars of the Muslim saints. Old discussions among ulama about the necessity of celebrating Nowruz acquired other forms in the 19th century: certain

\footnotetext{
*In some documents of the Russian authorities in Samarkand, instead of the word "Nowruz", the folk term sayl was used.
} 
principles and the large scale of celebrations were criticized. This criticism obviously had contributed to the decrease of celebration during the rule of subsequent emirs. Folk celebration of Nowruz differed from the official one in that it included the rituals of ancestor worship, with the visits of saint mazars.

In Samarkand, with its polyethnic population, closer contacts between the settled Tajiks and Uzbeks, on the one hand, and the semi-nomadic Turks, on the other, enhanced the synthesis of agricultural and pastoral elements in the ritual practice of Nowruz. Establishment of the distinct Muslim and European parts of the city affected the principle of holiday organization. Upon annexation of Samarkand by the Russian Empire, the scale of Nowruz celebration decreased.

\section{Acknowledgement}

This study was supported by the European Regional Development Fund, Project CZ.02.1.01/0.0/0.0/16_019/0000791.

\section{References}

\section{Abdirashidov Z. 2011}

Annotirovannaya bibliografiya turkestanskikh materialov v gazete "Tarzhuman" (1883-1917). Tokyo: Department of Islamic Area Studies, Center for Evolving Humanities, Graduate School of Humanities and Sociology, The University of Tokyo. (Central Eurasian Research Series; No. 5).

\section{Al-Ghazali Muhammad Abu Hamid. 2018}

Kimiya-yi sa'adat (Eliksir schastya). Vol. 2: Rukn 2: Obychai, A.A. Khismatulin (transl. from Persian and intr.). St. Petersburg, Kazan: Peterburg. Vostokovedeniye.

\section{Andreev M.S., Chekhovich O.D. 1972}

Ark (kreml) Bukhary v kontse XIX-nachale XX vv. Dushanbe: Donish.

\section{An-Narshakhi Abu Bakr Muhammad ibn Jafar. 2011}

Ta'rikh-i Bukhara: Istoriya Bukhary, S.S. Kamoliddin (transl., comm., notes), E.G. Nekrasova (comm.). Tashkent: SMI-ASIA.

\section{Arendarenko G. 1877}

Iz Samarkanda. Turkestanskiye vedomosti, No. 19.

Ayni S. 1960

Vospominaniya. Moscow, Leningrad: Izd. AN SSSR.

Ayni S. 1975

Istoriya mangytskikh emirov. In Sobraniye sochineniy, vol. 6. Moscow: Khudozh. lit., pp. 266-312.

\section{Braginsky I.S. 1977}

Prazdnik vesny - Nouruz i otrazheniye v nyom drevneishikh obshchikh kulturnykh traditsiy narodov sovetskogo Vostoka. In Braginsky I.S. Issledovaniya po tadzhikskoy kulture. Moscow: Nauka, pp. 113-120.

\section{Dorzhieva D.D. 2016}

Kalendarniye prazdniki i obychai uigurov v kontekste obryadovoy kultury narodov Tsentralnoy Azii. Ulan-Ude: Izd. Buryat. Gos. Univ.

\section{Etzioni A. 2004}

Holidays and rituals: Neglected seedbeds of virtue. In We Are What We Celebrate: Understanding Holidays and Rituals, Amitai Etzioni, Jared Bloom (eds.). New York: New York Univ. Press, pp. 1-40.

\section{Grebenkin A.D. 1872}

Tadzhiki. In Russkiy Turkestan: Sbornik, izdanniy po povodu politekhnicheskoy vystavki, iss. 2, V.N. Trotsky (ed.). Moscow: [Universitet. tip.], pp. 1-50.

\section{Grenet F. 2006}

What was the Afrasiab painting about? In Royal Nauruz in Samarkand: Proceedings of the Conference Held in Venice on the Pre-Islamic Paintings at Afrasiab, M. Compareti, E. de la Vaissiere (eds.). Pisa, Roma: Academia editoriale, pp. 43-50.

\section{Haj S. 2009}

Reconfiguring Islamic Tradition: Reform, Rationality, and Modernity. Stanford: Stanford Univ. Press.

Khoroshkhin A.P. 1876

Sbornik statey, kasayushchikhsya do Turkestanskogo kraya. St. Petersburg: [Tip. i khromolit. A. Transhelya].

\section{Lobacheva N.P. 1986}

$\mathrm{K}$ istorii kalendarnykh obryadov u zemledeltsev Sredney Azii. In Drevniye obryady, verovaniya i kulty narodov Sredney Azii: Istoriko-etnogr. ocherki. Moscow: Nauka, pp. 6-31.

\section{Lobacheva N.P. 1995}

Ogni safara v Khorezme (o zabytykh prazdnikakh). Etnograficheskoye obozreniye, No. 5: 24-36.

Locke J. 1906

New Year's festival at Bokhara. Outing, vol. 47 (4): 387-398.

\section{Magiya Navruza. 2007}

S. Abdullo (comp.). Almaty: Atamura.

\section{Malikov A.M. 2018}

Tyurkskiye etnonimy i etnotoponimy doliny Zerafshana (XVIII-nachalo XX v.). Tashkent: Muharrir nashriyoti.

\section{Rakhimov R.R. 2012}

Nikholi 'umr: Derevo v miforitualnoy simvolike tadzhikov. In Tsentralnaya Aziya: Traditsiya v usloviyakh peremen, iss. III. St. Petersburg: MAE RAN, pp. 106-159.

\section{Rempel L.I. 1972}

$\mathrm{Ob}$ otrazhenii obrazov sogdiyskogo iskusstva $\mathrm{v}$ islame. In Iz istorii iskusstva velikogo goroda: (K 2500-letiyu Samarkanda). Tashkent: Izd. literatury i iskusstva, pp. 36-52.

\section{Rempel L.I. 1981}

Dalekoye i blizkoye: Stranitsy zhizni, byta, stroitelnogo dela, remesla i iskusstva Staroy Bukhary. Bukharskiye zapisi. Tashkent: Izd. literatury i iskusstva.

Rossiya: Polnoye geograficheskoye opisaniye nashego otechestva: Nastolnaya i dorozhnaya kniga dlya russkikh lyudei. 1913

V.P. Semenov Tyan-Shansky (ed.), P.P. Semenov TyanShansky, V.I. Lamansky (head.). Vol. 19: Turkestanskiy krai, V.I. Masalsky (comp.). St. Petersburg: A.F. Devrien.

\section{Samoylovich A. 1922}

Pervoye tainoye obshchestvo mladobukhartsev. In Vostok, bk. 1. Peterburg: Vsemir. lit., pp. 97-99.

\section{Shcherbak A.M. 1974}

Sal-name (po rukopisi V 721, khranyashcheisya v Rukopisnom otdele LO IV AN SSSR). In Pismenniye pamyatniki Vostoka: Istoriko-filologicheskiye issledovaniya: Yezhegodnik. 1971. Moscow: Nauka, pp. 171-189. 
Siddikiy Azhziy. 2005

Tashakkur va rizho. In Ismoilbek Gasprinskiy va Turkiston, N. Karimov (masul mukharrir). Tashkent: Shark, pp. 140-143.

Snesarev G.P. 1969

Relikty domusulmanskikh verovaniy i obryadov u uzbekov Khorezma. Moscow: Nauka.

Sukhareva O.A. 1966

Bukhara v XIX - nachale XX v. (pozdnefeodalniy gorod i ego naseleniye). Moscow: Nauka.

Sukhareva O.A. 1986

Prazdnestva tsvetov u ravninnykh tadzhikov (konets XIXnachalo XX v.). In Drevniye obryady, verovaniya i kulty narodov Sredney Azii. Moscow: Nauka, pp. 31-46.

Traktat Akhmada Donisha "Istoriya mangytskoy dinastii". 1967

I.A. Nadzhafova (transl., intro, and comm.). Dushanbe: Donish.
Turner V. 1983

Simvol i ritual. Transl. from English. V.A. Baileys (intr.). Moscow: Nauka.

Ustaev S.U. 1985

Noviy god (Navruz) v mifologicheskikh vozzreniyakh tadzhikov i uzbekov. Sovetskaya etnografiya, No. 6: 97-104.

V.V. [Vyatkin]. 1897

Nauruz v Samarkande. Turkestanskiye vedomosti, No. 14.

Veselovsky N.I. 1888

Ramazan v Samarkande i Kurban-bairam v Bukhare. Istoricheskiy vestnik, No. 33: 141-147.

Zapiski o Bukharskom Khanstve: (Otchety

P.I. Demezona i I.V. Vitkevicha). 1983

Moscow: Nauka.

Received November 3, 2019. Received in revised form November 20, 2019. 